\title{
Socio-economic factors that impact the desire to protect freshwater flow in the Rio Grande, USA
}

\author{
D. W. Yoskowitz \& P. A. Montagna \\ Harte Research Institute for Gulf of Mexico Studies, \\ Texas A\&M University-Corpus Christi, USA
}

\begin{abstract}
Water has value in its many different uses, such as drinking, irrigation, cooling, etc. What is the value of water when it is not used at all, but remains in its body or course for what is referred to as "environmental flow"? Reducing freshwater flow in rivers and inflow into estuaries can lead to a loss of biodiversity, critical habitat, and important commercial and recreational fisheries. While individuals rarely use freshwater flow directly, they benefit from the impact that this flow has on ecosystem services, primarily in the area of recreation and ecotourism. This paper provides a new approach to valuing environmental flow. Interviews were conducted, in person, with 417 people in the Spring of 2007 in the Lower Rio Grande Valley to ascertain what households were 'willing-to-pay' to protect environmental flow. A double bounded-dichotomous choice (DBDC) contingent valuation technique was employed. Sixty-four percent $(64 \%)$ said they would be willing to make a one-time donation to a 'water trust'. Through statistical analysis of the survey responses we are able to derive a mean value for freshwater flow: \$129. Applying what people are willing to pay (\$129) to the relevant population of recreationists and conservationists, as these are the individuals that are most likely to donate, generates an aggregate value of $\$ 9.9$ million.
\end{abstract}

Keywords: contingent valuation, freshwater inflow, ecosystem services, environmental flow. 


\section{Introduction}

What is the value of freshwater flow in the Lower Rio Grande? How do you value something when there is no traditional market that exists for it? This is the challenge faced by those who wish to calculate a monetary value on many environmental and ecological assets. For policymakers it is a necessity to place a value on alternatives states of being especially when the costs and benefits of a particular decision are being weighed.

Water has value in its many different uses, such as drinking, irrigation, cooling, etc. What is the value of water when it is not directly used at all, but remains in its body or course for what is referred to as "environmental flow"? More specifically, what is the value of freshwater flow in the Lower Rio Grande of Texas? There might be as many different answers as there are individuals that you ask. Commercial and recreational angler's perspective would most likely differ from birders who would most likely differ from water resource managers who would most likely differ from someone who does not use the resource at all.

Additionally, what determines how people value the resource? Is it simply a function of income or education or marital status? Could it be a sense of place? As important as understanding how the public values freshwater flow is what determines that value. This study sets out to calculate a non-market value for 'environmental flow' for the Rio Grande in state of Texas, USA.

\section{Ecological characteristics of freshwater inflows}

Historical studies have stressed the importance of freshwater inflow to estuarine systems, and note how inflow is a major factor driving estuary function and health (Chapman [1]; Kalke [2]). Coastal wetlands linked to estuaries provide food, protection, and nutrients to hundreds of species of birds, fish, and invertebrates.

A major role of river water flowing into bays is the dilution of seawater to create brackish conditions. Freshwater inflow and corresponding changes in salinity are the primary factors controlling the distribution of marine and freshwater organisms within an estuary (Kalke and Montagna [3, 4], Attrill et al. [5], Montagna et al. [6]). Many species utilize the lower salinity waters in bays for all or a portion of their life cycle (Longley [7]).

Inflows serve a variety of important functions in estuaries, including the creation and preservation of low-salinity nurseries, sediment and nutrient transport, allochthonous (outside) organic inputs, and assist in movement and timing of critical estuarine species (Livingston [8]; Longley [7]). Nutrients from freshwater become incorporated into the estuarine food web and help increase vegetation and enhance the secondary production in the area (Rozas et al. [9]). Freshwater also dilutes contaminants from upstream sources and plays an important role in the circulation of water masses and movement patterns of sediment (Longley [7]).

Texas' bays and estuaries are among the state's most valuable but underappreciated natural assets. These rich coastal ecosystems support important 
economic activities that include recreational and commercial fishing, birding, hunting, and ecotourism. All of these activities depend on healthy bays and estuaries, which in turn, depend on freshwater inflows from Texas' rivers and streams. Intensifying competition among upstream human water users however, is threatening the water supply of coastal ecosystems, threatening these valuable coastal and instream resources. Agricultural production, industry, and rapidly growing urban populations are claiming increasing portions of river flows.

Reducing freshwater flow in rivers and inflow into estuaries can lead to a loss of biodiversity, critical habitat, and important commercial and recreational fisheries. An increase in salinity can lead to alterations in species composition, diversity and distribution as well as increase the incidence of red tide and other harmful bacteria (Mathis et al. [10]). Texas bays and estuaries support several important recreational and commercial fishery industries, i.e. oysters and shrimp rely on estuaries for part of their life cycle. An increase in salinity can have negative effects on habitat, food and disrupt the food chain which will all have an effect on fisheries populations.

\subsection{The Lower Rio Grande}

The Rio Grande is the second longest river in North America, stretching from the Rocky Mountains to the Gulf of Mexico. The river is a major supplier of surface and ground water used residentially, commercially and agriculturally. The water from the river is also important in the formation and shaping of ecosystems of the Lower Rio Grande Valley. The mouth of the Rio Grande, where the fresh river water mixes with salt water from the Gulf of Mexico, is known as a 'minor bay.' Minor bays are river-dominated estuaries that drain directly into the Gulf of Mexico rather than into a bay. Freshwater inflow into minor bays is generally dominated by non-point source runoff or an indirect source via circulation from adjacent systems. These drowned-river valley ecosystems are thus uniquely different from the typical bar-built estuaries of Texas that are characterized by large open bays.

Historically, the Rio Grande periodically flooded the Lower Rio Grande Valley and supplied freshwater to the thorn thicket and sabal palm forests located in the area. The flooding occasionally cut channels in the delta creating lakes known as 'resacas' (Mathis et al. [10]). The water from the floods provided an important source of freshwater for terrestrial and estuarine ecosystems in the Valley. Due to construction of the Falcón and Amistad reservoirs in 1954 and 1968 and soon the Brownsville weir and reservoir, it is believed the river will never return to its natural flow regime (Mathis et al. [10]).

Figure 1 shows how reduced river flows can alter the normal functions of the Rio Grande estuary. Alteration of flows can lead to a loss in sediment transport, decrease in nutrients, and loss of marshes and wetlands. The effect of these alterations is a loss of habitat, productivity and secondary production and eventually revenue.

Recently an increase in water usage and environmental factors, such as drought conditions, have reduced the flow of water to the Gulf of Mexico and surrounding environments. Significant changes to habitat downstream of the 
reservoirs and dams have been noted, i.e. due to alterations in freshwater flows habitat has decreased altering the flows of sediment and nutrients. In 2002 and 2003 river flow was so low a sand bar formed at the mouth of the Rio Grande which caused the river to be cut off from the Gulf and interrupted normal estuary functions. Preliminary results of a study on the estuarine area of the river from Texas Parks and Wildlife showed that while the river was closed off from the Gulf, organism counts decreased (Mathis et al. [10]). Gulf fish and shrimp that use the estuary for nursery purposes disappeared from species counts, however blue crab populations increased due to the lowered salinity and reduced predator numbers from the Gulf. The once estuarine ecosystem was beginning to resemble a freshwater environment which can be detrimental to many species.

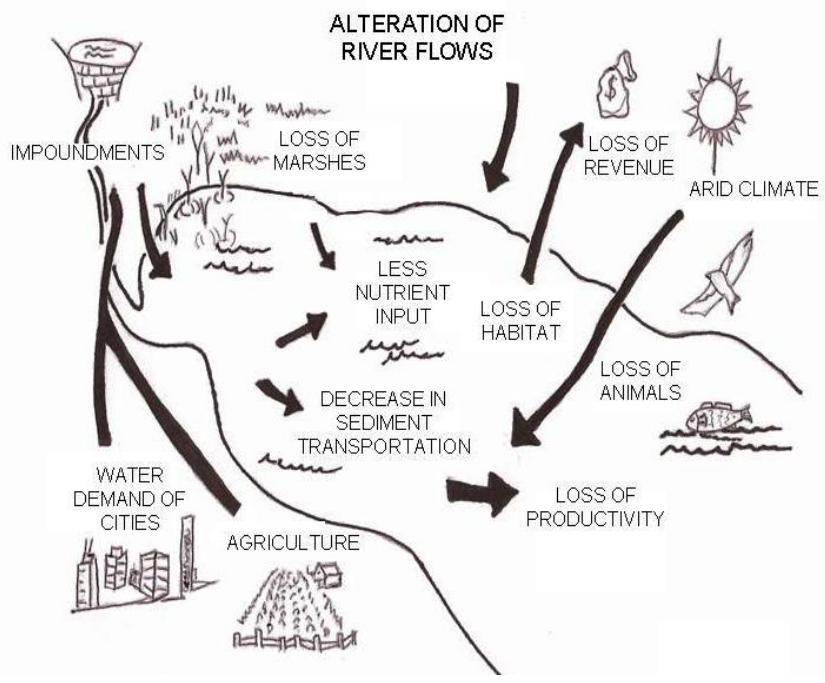

Figure 1: Effects of alteration of Rio Grande flows.

\section{Methodological approach}

There are a number of approaches to valuing non-market ecological assets and the ecosystem services they produce. The appropriate technique depends upon many factors including: type of resource to be valued, budget, time frame, and use of the results. Economic agents engage in real, market activities and the values they place on goods and services is revealed through their actual behavior. If markets do not exist for the goods or services, then hypothetical scenarios are created to elicit the values that individuals would place on the nonmarketed good and this value preference is stated.

The technique employed for this study is the contingent valuation $(\mathrm{CV})$ method. In general the CV method estimates the value of the non-market goods through questions in a survey format. The respondents state their preferences in terms of willingness-to-pay for a good or service or willingness-to-accept if they 
cannot use the good or service. The values placed on the good or services are contingent upon the structure of the hypothetical market (Brookshire and Eubanks, [11], Brookshire and Randall, [12], Whitehead, [13]).

Earlier in its development and use, this method was not without controversy. The basic argument against was "...that real transactions are much more reliable indicators of value than self-reported behavioral intentions" (Randall, [14]).The debate came to a head as a result of the Exxon Valdez oil spill in 1989 and the use of $\mathrm{CV}$ in assessing damages. Both sides argued aggressively for the merits and perceived shortcomings of the technique.

In order to settle many of the ongoing issues, the general counsel of NOAA formed a panel of experts, chaired by two Nobel laureates in economics, to provide a recommendation on the use of $\mathrm{CV}$ for estimating non-use values. Their report concluded, "CV studies can produce estimates reliable enough to be a starting point for a judicial or administrative determination of natural resource damages---including passive use values" (Arrow et al. [15]).

While there continues to be some detractors of the CV method, its lengthy history and continued use show it to be well vetted. Mathis et al. [16] sum it up nicely "...CV is the only economic method available for measuring non-use values associated with nature".

\subsection{Valuation methods}

For the purposes of valuing freshwater inflow we utilize the stated preference approach of contingent valuation method (CVM). This approach uses hypothetical choice data to estimate the ex-ante willingness to pay for various non-market commodities (Brown [17]). This approach can be used to construct realistic policy options, through hypothetical choices, in order to gain information about the policy (Whitehead [13]). The major weakness of the stated preference approach is the hypothetical nature of the exercise. The respondent is placed in a situation that they are not completely familiar with and information about the commodity or program might be incomplete.

The hypothetical situation in the freshwater flows survey involves two decisions, following Whitehead et al. [18]. First, the survey respondents decide if they are willing to pay something. If they are willing to pay something, then the respondents decide if they are willing to pay the specific amounts presented to them in order to protect freshwater flow. Specifically, we employ a doublebounded dichotomous choice (DBDC) format to elicit the respondent's willingness to pay. The response sequences are: yes-yes, yes-no, no-yes, no-no. The probabilities of each are as follows:

$$
\begin{gathered}
\operatorname{Pr}(\text { yes, yes })=\operatorname{Pr}\left(W T P_{1 j} \geq B I D^{1}, W T P_{2 j} \geq B I D^{2}\right) \\
\operatorname{Pr}(\text { yes, no })=\operatorname{Pr}\left(W T P_{1 j} \geq B I D^{1}, W T P_{2 j}<B I D^{2}\right) \\
\operatorname{Pr}(\text { no, yes })=\operatorname{Pr}\left(W T P_{1 j}<B I D^{1}, W T P_{2 j} \geq B I D^{2}\right) \\
\operatorname{Pr}(\text { no, no })=\operatorname{Pr}\left(W T P_{1 j}<B I D^{1}, W T P_{2 j}<B I D^{2}\right)
\end{gathered}
$$

where $B I D$ is the bid amount for the first and second bids faced by the $j^{\text {th }}$ respondent. 
If $y_{1 j}=1$ the response to the first question is yes, and 0 otherwise, $y_{2 j}=1$ if the response to the second question is yes, and 0 otherwise. Following Alberini et al. [19] the $j^{\text {th }}$ contribution to the bivariate probit log likelihood function becomes:

$$
\begin{aligned}
\log L_{B P} & =\sum_{j=1}^{n}\left(1-y_{1 j}\right) *\left(1-y_{2 j}\right) * \pi_{j}^{N N}+\left(1-y_{1 j}\right) * y_{2 j} * \pi_{j}^{N Y} \\
& +y_{1 j} *\left(1-y_{2 j}\right) * \pi_{j}^{Y N}+y_{1 j}^{*} y_{2 j} * \pi_{j}^{Y Y}
\end{aligned}
$$

where $\pi_{j}^{N N}, \pi_{j}^{Y N}, \pi_{j}^{N Y}, \pi_{j}^{Y Y}$ are the probabilities of each pair of responses that are calculated from the bivariate normal cumulative distribution function. Mean willingness to pay is calculated as:

$$
W T P=\frac{\alpha}{\hat{\beta}_{B I D}}+\sum_{z=1, \neq B I D}^{n} \frac{\hat{\beta}_{z}^{*} \bar{z}}{\hat{\beta}_{B I D}}
$$

Where $\alpha$ is the constant, $\hat{\beta}$ is the estimate of the coefficient, and $z$ is the vector of variables that are arguments in the estimation. Therefore the mean WTP is the constant, from the estimation results, divided by the estimated coefficient of the BID variable $\left(\hat{\beta}_{B I D}\right)$, plus the sum of the remaining explanatory variables multiplied by their mean values, except BID, divided by $\hat{\beta}_{B I D}$.

\section{Survey and results}

The survey describes and illustrates the relationship of freshwater inflow to the bays and estuaries ecosystem and the current issues surrounding the protection of that inflow. In addition, it asks about the respondents recreational activities in the region, describes a Trust that would be used to deposit water rights into and therefore protect inflow, elicits their willingness to pay, and demographic information.

The survey instrument for the Lower Rio Grande Valley presented information on freshwater flow and its impact on the marshes, estuaries, and river and included visual aids (such as figure 1). After the background information was complete, respondents were then asked if they would donate to a fund that would protect freshwater flow. Surveying of 417 individuals took place in the Spring of 2007 in person and on site in the Lower Rio Grande Valley. Individuals that benefit form the resource as well as the general public were targeted.

\subsection{Descriptive statistics}

Table 1 presents the Socio-economic descriptive statistics of the survey respondents. An overwhelming majority of respondents $(81.5 \%)$ said that they had visited the region for the purpose of engaging in outdoor recreational 
activity. This result was to be expected since this was our target population. The top three activities out of a list of nine, were: (1) bird watching; (2) nature observation; and (3) beach going.

Interestingly, only a small percentage $(36 \%)$ are members of a conservation/environmental organization yet eighty-two percent (82\%) said that they recreate in the regions bays and estuaries. A majority of the respondents were Texas residents (63\%), male (53\%), and white/Caucasian (53.4\%). The average education level would be equivalent to an associates degree and fortynine percent of the respondents household income was in the top two quintiles (greater than \$45,001).

The hypothetical market is described next. Water rights would be bought through this program then deposited with the Texas Water Trust. A donation scheme is much more palatable than a taxing mechanism, especially in Texas. It is also the most realistic scenario. The voluntary contributions would be used to purchase $X \%$ of freshwater inflow. The percentage amount $X$ was randomly assigned from three amounts: $5 \%, 10 \%$, and $15 \%$.

Table 1: $\quad$ Socio-economic data.

1. Knowledge of regions wetlands and marshes: a lot

Some $\quad 22 \%$

A little $\quad 30 \%$

Nothing $\quad 33 \%$

$\underline{\text { Yes } \quad \text { No }}$

2. Member of conservation/environmental organization

3. Texas resident

$63 \%$

4. Recreate in Rio Grande Valley nature areas

$\begin{array}{rrrr} & 36 \% & & 64 \% \\ & 37 \% & & \\ 82 \% & & 18 \% & \end{array}$

5. Sex: $\quad$ Male $53 \% \quad$ Female $47 \%$

6. Ethnicity: White/Caucasian $53.4 \%$

African-American $\quad 0.5 \%$

Latino/Hispanic $43.7 \%$

Asian-American $\quad 0.7 \%$

Other $\quad 1.7 \%$

7. Education:

Average 14.3 years

Median 15 years

8. Household Income:

Less than $\$ 15,000$

$11 \%$

$\$ 15,001-\$ 30,00021 \%$

$\$ 30,001-\$ 45,00019 \%$

$\$ 45,001-\$ 75,00027 \%$

Greater than $\$ 75,000$

$15 \%$ 
donated is greater than the amount required to purchase and protect $X \%$ of freshwater inflows, the extra money would be used to provide public access and educational sites in the region."

There are two important questions that were asked of the respondents that seem similar but address two different issues. The first question asks: "Would you be willing to make a one-time donation of money in order to purchase water rights and protect freshwater inflows within the next 12 months?" Sixty-four percent $(64 \%)$ said they would be willing to make a one-time donation. Twentyseven $(27 \%)$ percent would not be willing and nine percent $(9 \%)$ did not know (Table 2).

The second question starts the willingness to pay assessment. For those respondents that are willing to make a donation they were read the following: "If about $1 \%$ of all households in Texas made a one-time donation of \$P there would be enough money to purchase and protect $\mathrm{X} \%$ of current inflows. Remember if you made a one-time donation of \$P you would have \$P less to spend on other things. Also remember that the protected water would not be available for any other use." Reminding the respondent of the impact on their budget constraint, as well that the resource is not unlimited, is an important component to eliciting efficient willingness to pay responses. The initial donation amount was randomly assigned from the following amounts: $\$ 20, \$ 40$, $\$ 80, \$ 100, \$ 150$, and \$200.

Following this initial valuation question there was a follow up valuation question. If the respondent answered "yes" to the initial donation amount then the follow up donation amount would be doubled from the initial amount. If they answered "no" the follow up amount would be half the original. For example, if they said "yes" to and initial bid of $\$ 40$ they would be presented with a next bid of $\$ 80$. If they said "no" the initial bid of $\$ 40$ they would be presented with a next bid of $\$ 20$.

Table 2: $\quad$ Valuation descriptors.

2. How sure are they that they would make a donation in the amount of \$P Scale of 1 to 10 , with 10 as definitely sure

Average 7.9

Median 8.0

3. Likelihood that $1 \%$ of all Texas households will make a one time donation of \$P

$\begin{array}{lr}\text { Very likely } & 11 \% \\ \text { Somewhat likely } 40 \% & \\ \text { Somewhat not likely } & 29 \% \\ \text { Not likely at all } & 20 \%\end{array}$




\subsection{Results}

The dependent variable in assessing willingness to pay is whether or not the respondent is willing to pay the requested donation to be made to the Texas Water Trust. As suggested by Groothuis and Whitehead [20] the "don't know" responses are recoded to "no" for the most conservative estimate.

The independent variables were selected in order to generate a more complete estimate that takes into account economic and demographic factors. As the bid (BID) amount increases the probability of responding "yes" and therefore the willingness to pay, should decrease. Income and education should be positively related with the probability of willingness to pay. In addition, we ask whether the respondent is a Texas resident, in order identify the important "Winter Texan" population. We hypothesize that being a resident would improve the probability of saying "yes".

Table 3 presents the results of the two estimations: Model 1 where the BID level is the only explanatory variable included, and Model 2 where the more complete model includes both economic and demographic variables. BID is highly significant in both models and negatively related to the probability of saying yes. Income and education are positively related to the probability of saying yes.

As stated above, the significant difference between the two models is the inclusion of economic and demographic variables. This inclusion tempers the WTP estimates. When BID is the only explanatory variable mean $\mathrm{WTP}=\$ 135$. When the additional variables are included mean WTP $=\$ 129$.

Table 3: Probit estimation.

\begin{tabular}{|c|c|c|c|c|c|c|}
\hline \multirow[b]{3}{*}{ Constant } & \multicolumn{3}{|c|}{ Model 1} & \multicolumn{3}{|c|}{ Model 2} \\
\hline & \multicolumn{3}{|c|}{ Coefficient t-statistic } & \multicolumn{3}{|c|}{ coefficient t-statistic } \\
\hline & & .538 & 5.757 & & $-0.1 \overline{74}$ & -0.633 \\
\hline BID & -0.004 & -5.973 & & & -0.005 & -6.346 \\
\hline Resident & & & & 0.01 & 0.07 & \\
\hline Education & & & & & 0.031 & 1.783 \\
\hline Income & & & & 0.115 & 2.237 & \\
\hline $2 *$ LL Ratio & & .091 & & & & 869 \\
\hline$p$-value & & .00 & & & & 00 \\
\hline WTP & & 35 & & & 129 & \\
\hline
\end{tabular}

\subsection{A context for the value}

Values for anything are fluid, dynamic, constantly changing whether it is for apples, umbrellas, or a fishing trip and these values are dependent upon the circumstances that individuals find themselves in. Many different factors influence these values including taste and preferences and income. When these change, then most likely values will change. 
While the same survey, in the same locations, at a different point in time would most likely generate a different value for freshwater flow protection, the most noteworthy result was that there were a significant number of individuals that were willing to donate a positive amount in order to protect freshwater flow. That, in and of itself, is a very telling result. From the perspective of trying to drive policy, NGOs should be encouraged by this.

However, in order to provide a better context for the values that are shown in Table 3, we aggregate them over the target population; resource users or individuals that recreate in the defined region. Previous studies have shown that more than one-third (35\%) of Texans said they participated in outdoor recreation activities close to home on a regular basis (Scott and Kim [21]).

The relevant population for the Lower Rio Grande Valley is sixty four percent (positive responses to the survey) of $1 / 3$ of the households (those that recreate) or 64,199. Plus 12,227 winter Texans. Multiplying the sum of those two figures by the mean WTP of $\$ 129$, we derive an aggregate value of $\$ 9,858,954$.

\section{Conclusions}

This study provides an initial look at the value that Texans place on freshwater flow or "environmental flow" in the Lower Rio Grande. Using contingent valuation we have estimated that value associated with protecting five percent $(5 \%)$ of freshwater inflow

A significant number of individuals surveyed (64\%) stated that they would donate some amount of money in order to protect freshwater inflow even when a majority $(64 \%)$ are not members of a conservation/environmental organization. The mean willingness to pay of $\$ 129$ reflects the value placed of freshwater inflow protection by those that were surveyed in the target population. An aggregate value of $\$ 9.9$ million is attributed to the relevant number of households in the Lower Rio Grande Valley.

It is evident that the value of environmental flow in the lower Rio Grande is considerable. However, the aggregate value is very conservative as it does not take into account households throughout Texas. It is well known that individuals from all over the State come to this region for recreation. Future studies might include a statewide survey to assess the economic significance of freshwater flow not only in the lower Rio Grande but the State's other rivers, bays, and estuaries.

\section{References}

[1] Chapman, E.R., The Texas basins project. In: R.F. Smith, A.H. Swartz, and W.H. Massmann (Editors), A symposium on estuarine fisheries. Am. Fish. Soc., 95(3), pp. 83-92, 1966.

[2] Kalke, R.D., The effects of freshwater inflow on salinity and zooplankton populations at four stations in the Nueces-Corpus Christi and CopanoAransas Bay systems, TX from October 1977-May 1975. Proceeding of the International Symposium on Freshwater Inflow to Estuaries, eds. R.D. 
Cross and D.L. Williams, Washington, DC: U.S. Dept. Int. Fish \& Wildlife, pp. 454-471, 1981.

[3] Kalke, R.D. and Montagna, P.A., A Review: The effect of freshwater inflow on the benthos of three Texas estuaries, pp. 185-218. In: P.A. Montagna (principal investigator) Nitrogen Process Studies (NIPS): The Effect of Freshwater Inflow on Benthos Communities and Dynamics. University of Texas Technical Report No. TR/89-011. 370 pp, 1989.

[4] Kalke, R.D. and Montagna, P.A., The effect of freshwater inflow on macrobenthos in the Lavaca River Delta and Upper Lavaca Bay, Texas. Contrib. Mar. Sci., 32 pp. 49-71, 1991.

[5] Atrill, M.J., Rundle, S.D., and Thomas, R.M., The influence of droughtinduced low freshwater flow on an upper-estuarine macroinvertebrate community. Water Res., 30 pp. 261-268, 1996.

[6] Montagna, P.A., Kalke, R.D., and Ritter, C., Effect of restored freshwater inflow on macrofauna and meiofauna in Upper Rincon Bayou, Texas, USA. Estuaries, 25 pp. 1436-1447, 2002.

[7] Longley, W.L. (ed). Freshwater Inflows to Texas Bays and Estuaries: Ecological Relationships and Methods for Determination of Needs. Texas Water Development Board and Texas Parks and Wildlife Department, Austin, TX, 386 pp, 1994.

[8] Livingston, R.J., Historical relationships between research and resource management, Apalachicola River Estuary, 1(4), pp. 361-382, 1991.

[9] Rozas, L.P., Minello, T.J., Munuera-Fernandez, I., Fry, B., and Wissel, B., Macrofaunal distributions and habitat change following winter-spring releases of freshwater into the Breton Sound estuary, Louisiana (USA). Estuar. Coast. Shelf S., 65, pp. 319-336, 2005.

[10] Mathis, M., Matisoff, D., and Haut, R., The Role of Freshwater Inflows in Sustaining Estuarine Ecosystem Health in the Lower Rio Grande Valley. Houston Advanced Research Center, The Woodlands, TX, 2006.

[11] Brookshire, D. S., and L. S. Eubanks, Contingent Valuation and Revealing Actual Demand for Public Environmental Commodities, manuscript, University of Wyoming, 1978.

[12] Brookshire, D. S., and A. Randall, Public Policy Alternatives, Public Goods, and Contingent Valuation Mechanisms, Paper presented at the Western Economic Association Meeting, Honolulu, Hawaii, 1978.

[13] Whitehead, J.C., A Practioner's Primer on Contingent Valuation. Department of Economics, East Carolina University, 2000.

[14] Randall, A., The NOAA Panel Report: A new beginning or the end of an era?,. American Journal of Agricultural Economics, 79, pp.1489-1494, 1997.

[15] Arrow, K., R. Solow, P.R. Portney, E.E. Leamer, R. Radner, and H. Schuman, Report of the NOAA Panel on Contingent Valuation. Federal Register 58, pp. 4601-14, 1993.

[16] Mathis, M.L., A.A. Fawcett, and L.S. Konda, Valuing Nature: A Survey of the Non-Market Valuation Literature, Houston Advanced Research Center, VNT-03-01, 2003. 
[17] Brown, T.C., Introduction to Stated Preference Methods. A Primer on Nonmarket Valuation, eds. P.A. Champ, K.J. Boyle, and T.C. Brown, Kluwer: Dordrecht and Boston, pp. 99-110, 2003.

[18] Whitehead, J.C., P.A. Groothuis, R. Southwick, P. Foster-Turley, Economic Values of Saginaw Bay Coastal Marshes, manuscript, June, 2006.

[19] Alberini, A., B. Kanninen, and R.T. Carson, Modeling response incentive effects in dichotomous choice contingent valuation data", Land Economics, 73(3), pp. 302-24, 1997.

[20] Groothuis, P.A. and J.C. Whitehead, Does don't know mean no? Analysis of 'don't know' responses in dichotomous choice contingent valuation questions, Applied Economics, 34(15), pp. 1935-1940, 2002.

[21] Scott, D. and C. Kim, Outdoor Recreation Participation and Barriers to Involvement, Technical Report for Texas Parks and Wildlife Department, Austin, TX,. August. 1998. 